First Peoples Child \& Family Review

An Interdisciplinary Journal Honouring the Voices, Perspectives, and Knowledges of First Peoples through Research, Critical Analyses, Stories, Standpoints and Media Reviews

\title{
Inferiorizing Indigenous Communities and Intentional Colonial Poverty
}

\section{Steven W. Koptie and Cynthia Wesley-Esquimaux}

Volume 5, Number 2, 2010

URI: https://id.erudit.org/iderudit/1068935ar

DOI: https://doi.org/10.7202/1068935ar

See table of contents

Publisher(s)

First Nations Child and Family Caring Society of Canada

ISSN

1708-489X (print)

2293-6610 (digital)

Explore this journal

Cite this article

Koptie, S. \& Wesley-Esquimaux, C. (2010). Inferiorizing Indigenous

Communities and Intentional Colonial Poverty. First Peoples Child \& Family

Review, 5(2), 96-106. https://doi.org/10.7202/1068935ar

\section{Article abstract}

This paper is a reflective topical autobiography of a man seasoned by thirty years of community and crisis work. It has been written to encourage Aboriginal peoples to reflect on their lives and share their lived-experiences with others so that we can work together to break the colonial spell that has held so many hostage to their past.
This document is protected by copyright law. Use of the services of Érudit (including reproduction) is subject to its terms and conditions, which can be viewed online.

https://apropos.erudit.org/en/users/policy-on-use/ 


\section{First Peoples Child \& Family Review}

An Interdisciplinary Journal Honoring the Voices, Perspectives and Knowledges of First Peoples through Research, Critical Analyses, Stories, Standpoints and Media Reviews

Volume 5, Number 2, 2010, pp. 96-106

\section{Inferiorizing ${ }^{1}$ Indigenous Communities and Intentional Colonial Poverty}

\section{Steven W. Koptie ${ }^{a}$ with Editorial Assistance from Cynthia Wesley-Esquimaux ${ }^{b}$}

\footnotetext{
1 This term comes from the mind and experiences of Indigenous author, Lee Maracle, during wonderful dialogic exchanges in her classes at the Centre for Aboriginal Initiative.
}

\begin{abstract}
${ }^{a}$ Mr. Koptie returned to academia in his 5 th decade, and successfully graduated from OISE at the University of Toronto in 2010. He won the Presidents Award for Top Aboriginal Graduate Student after fighting hard to be admitted to graduate studies as an adult learner. Steven is a glowing example of the diversity of individuals who constitute Indigenous scholars in the academy. He notes that returning to school can enrich not only your own life, but inform and dispel the many myths that plague and undermine relationship building between Aboriginal and Canadian citizens in this country.

${ }^{b}$ Ph.D., Nexen Chair in Aboriginal Leadership, Chippewa of Georgina Island First Nation, Ontario.
\end{abstract}

\section{Introduction}

To paint a picture of the Canada that Aboriginal people envision I need only turn to the ideals of a good life embedded in Aboriginal languages and traditional teachings. The Anishinabek [Great Lakes people] seek the spiritual gift of "piimatizwin"- long life and wellbeing, which enable a person to gain wisdom. The Cree of the northern prairies value "miyowicehtowin" - having good relations. The Iroquois [Six Nations] Great Law sets out rules for maintaining peace "Skennen kowa" between peoples, going beyond resolving conflicts to actively caring for each other's welfare. Aboriginal peoples across Canada and around the world speak of their relationship with the natural world and the responsibility of human beings to maintain balance in the natural order. Rituals in which we give something back in return for the gifts that we receive from Mother Earth reinforce that sense of responsibility.

I would guess that most Canadians subscribe to these same goals: long life, health and wisdom for self and family; a

Questions or correspondence concerning this article may be addressed to:

koptie.steven@gmail.com

\section{Abstract}

This paper is a reflective topical autobiography of a man seasoned by thirty years of community and crisis work. It has been written to encourage Aboriginal peoples to reflect on their lives and share their lived-experiences with others so that we can work together to break the colonial spell that has held so many hostage to their past.

Key Words: Indigenous Scholars, demystify, decolonize, colonialism, Cultural Safety.

harmonious and cohesive society; peace between peoples of different origins and territories; and a sustainable relationship with the natural environment. Canadians would probably also agree in principle with the traditional Aboriginal ethic that our actions today should not jeopardize the health, peace and well-being of generations yet unborn.

(George Erasmus: The Lafontaine-Baldwin Lectures, Vancouver 2002)

There is a splendid reflexivity in identifying as an Indigenous scholar. Demystifying denigrating misconceptions and worn out rationalizations of Victorian age myths of British hegemony, imperialism, and a perverse sense of entitlement to privilege is the modern warrior's way of re-contextualizing the experience of colonization.

The writer has had many difficult debates about "Aboriginal poverty" on Canadian reserves. My observation in working on northern Ontario fly-in reserves as a mental health worker is that while the residents of 'unnatural communities (reserves) may be materially poor in comparison to the unsustainable excesses of southern Canada, they remain tied, albeit precariously, to their ancestral lands. They stand in stark contrast to increasingly greedy citizens of southern Canada and those around the world who remain dependent on the stealing of natural resources from 


\section{Acknowledgements:}

Author Lee Maracle - I wish to send you a heart felt thank you for coining the term Inferiorizing and showing great kindness and generosity in guiding my written work through graduate studies at the University of Toronto. You remain an Indigenous writers' best ally and a remarkable SAGE (Supporting Aboriginal Graduate Enhancement) cultural guide. The concept of Inferiorizing Indigenous Communities was birthed from your wisdom and conversations about my wanting to explore and express Indigenous poverty from an Indigenous world-view.

Dr. Cynthia Wesley-Esquimaux - I, like many others, have gained significant insight on what truth and reconciliation can look like through the lenses of your passion and dedication to "Changing the Face of Aboriginal Canada," I can only say, "Many layers of thank you for your efforts".

Indigenous lands. Pirates continue to plunder riches from foreign places while renaming their destructive tendencies as progressive civilization. The question becomes how much of today's progress is based on utopia ideals by theorists unmoved by on the ground encounters to critically evaluate the costly-in-all-ways trajectories of modern mankind? Indigenous peoples stand as stark reminders that not all peoples endorse the realities created by privileged nobility that allow for less than $5 \%$ of the worlds population to own land. What is the recourse of future generations who exist beyond the consciousness of an Indigenous world-view. The conditions on many Canadian reserves mirror many locales across the globe where resource plundering and unjust land grabbing are tolerated because citizens are shielded from the real costs of freefall capitalism and development.

The oil sands of Alberta avidly represent the foolish innocence of too many Canadians and display a remarkable disrespect for the consequences of becoming a rich energy superpower. Dreier (2001) writes about place-based inequalities that create political and economic separation that lead to stereotypes where the privileged attack those who they identify as burdens when a fair costing of economic wealth must be determined. He writes "the development of "separate societies" for rich and poor not only directly increases income inequity by affecting access to jobs and education; it also generates dangerous stereotypes and tilts the political terrain." (Dreier, 2001:24). For Indigenous scholars this idea has contextual relevance but misses the Indigenous world-view that author John Mohawk invites us to contemplate. There is a huge gap in the rationales put forward to account for the "vicious circle of geographically rooted income inequities" (Dreier, 2001). They exclude a critical review of the failure of colonization and offer little hope for intellectual reclamation of an alternative Indigenous voice.

I was required to appeal a rejection of my application for graduate studies at the University of Toronto. My voice was not regarded as offering an equal contribution, even with my extensive community experience. It was the Supporting Aboriginal Graduate Enhancement (SAGE) group who advocated for recognition of the contributions my generation of social workers made. They spoke from within the walls of the academy, talking over the systemic barriers to Indigenous knowledge. Their support is instrumental in gaining recognition for our work as vital to informing the truth and reconciliation healing work Canada has stubbornly avoided. There is an attendant awkwardness in posing difficult questions or challenging myths that surround the failure to invite in or respect Indigenous passions. The academy, and Canada as State, would rather intimidate, coerce, and punish Indigenous peoples for their reluctance to assimilate, integrate and join modernization, globalization, and a form of civilization that very few human beings can actually share. Perhaps, that few even want to share. When victims of colonization trauma exhibit angst at the impositions of the settler state, express their suffering, or request truth regarding historical injustices, they are told they are lazy, ungrateful, and biting the hand that feeds them. What has happened is the silence has become deafening and the social pain remains a tangible reminder of that which is not.

This paper became a reflective topical autobiography, a research method learned from New Zealand Indigenous scholar Irihapeti Ramsden (2003). Her seminal work on Cultural Safety before she died deeply informed my research and writing path through graduate school (Koptie, 2009b). She began her Ph.D. thesis with what she terms a reflective topical autobiographical journey of self-discovery' to understand how her ancestors became the poorest members of colonial New Zealand;

Although the daughter of an historian I had little knowledge of the political history or the legislative manipulation of the ownership of Maori land and the social, economic, educational and legislative processes which led to the poverty of Maori people. ... I did not understand why Maori were stereotyped as unintelligent, irresponsible and lazy. Why Maori were demonised in the media, filled the prisons and hospitals and were told that they had the same opportunities for successful social accomplishment as everyone else. My whole experience showed me that there were fundamental and brutal injustices in our society and I wanted to know how and why they got there, how they worked and how they were sustained. (Irihapeti Ramsden, 2003) 
Indigenous scholars can emulate Irihapeti Ramsden's "melancholicjourneyofself-discovery" and publicenlightenment because it helps to frame and articulate how the Canadian Indian Act of 1876 legitimized colonization of a once sovereign people (Koptie, 2009b). The strained relations between Canadians and Indigenous people will likely not survive $21^{\text {st }}$ century sensitivities to social justice, and we all need to ensure the prevention of dangerous political, social, environmental and religious upheavals that threaten global well-being. Indigenous poverty must be framed from within the perspective of Cultural Safety. Irihapeti Ramsden was a path-finder in articulating ways to empower future generations in challenging the status quo. She demanded that we learn to respect and accommodate the diversity of humanity. She taught her students to resist and rebel against the ignorance and arrogance of the settlers of New Zealand and the sameness that continues to prevent deep soul searching of privileged colonizers in Canada. Ellison-Loshmann (2003) in her obituary for Ramsden shared a reflective narrative of an opening statement Ramsden made at a lecture in 2001. Ramsden challenged nurse trainees with the following; "there are three kinds of people; those who make things happen, those who watch things happen and those who never knew what hit them - let nurses be in the first category."

Itrequires extraordinarygood will to escapetheenmeshment of historic errors, misconceptions and misrepresentations and an urgent need to correct the ensuing injustices that marginalize, demean, diminish and destroy the lives of Indigenous peoples. Ramsden's movement towards a model of Cultural Safety is a superb road map to places of unity and collaboration for decolonization as well as equity of access for all of Creation's diverse human richness. She asked Moana Jackson to express the strengths of Cultural Safety in their sharing of reflective topical interviews (autobiographies). His narrative (Ramsden 2003:127), is the concluding thought to my reflections on the inferior communities that remain tolerated and unchallenged across Canada:

First, its strength is to challenge students to analyze where they've come from. I don't think we should under-estimate that in New Zealand educational system because there is one thing that education lacks in this country, it is the teaching of an ability to be critical, the colonizing mentality doesn't encourage criticism, it encourages conformity. But what Cultural Safety as an academic idea does, is that it re-invents or reclaims the need to critically analyse things, and I think that's most important and its greatest strength in a general academic sense.

In a more specific sense of nursing education, we as a people are not going to be able to remedy the unwellness of our people in six months or a year because it's the consequence of a hundred and fifty-seven years of dispossession. And so it's crucial that we have people working in that area who are actually going to help our people be well. And so, I think its strength is that it, it helps provide that in nursing education in a specific area. But then its broadest strength I think, is what we've been talking about a lot and that is, that a political idea and in the end remedying the ills of our people is a political and a constitutional issue, not in terms of the Beehive and Parliament, but in terms of changing the mindset of our people about our power and our powerlessness and so on. (Ramsden, 2003, thesis chapter 9:2)

Nurses are frontline witnesses to community development successes as well as failures and Ramsden's work on decolonization helps to re-vise, re-tell and recover valuable lessons from this writer's struggle to alter the trajectory of suffering in First Nations communities throughout a Canada in which a Prime Minister can go mostly unchallenged for declaring that, "Canada has no history of colonization" (Harper, 2009).

This is mostly because the historical narratives most citizens of Canada study rarely challenge the trajectory of colonial inertia from the perspective of its victims. Archer (2000) shares LeviStrauss's claim that history maintains a "closed system" that recounts the colonial narrative with little human experiential context;

History, in short, does not record or discover meaning; it does no more than provide a catalogue, which can serve as a point of departure in the quest for intelligibility. We must understand, that is, that there has been no progress of the kind that humanist historians suppose, no development of cognition, no dialectical process at work in human society, but merely the reformulation in numerous different guises of an essential structure of human knowledge - a structure which is, according to Levi-Strauss, a closed system. Historical thought is simply the humanist mythology by means of which the 'civilized' or 'developed' world relates to the discontinuous, objective and immutable structure of brain and psyche. (Archer in Soper, 2000:28)

Becoming an Indigenous scholar, writer and restorer of Indigenous meta-narratives to confirm our human rights to flourish in our homelands is a $21^{\text {st }}$ century response to the injustice, confusion and foolish prerogative power that provides for human atrocities like the 1876 Canadian Indian Act and an actual Canadian Department of Indian Affairs to manage, regulate and suppress one specific race and erode our humanity. To be able to record new truths about such fallacies is to realize the eternal survival of Indigenous people across Turtle Island [North America], and their will to not disappear through cultural, political, social and spiritual inertia. It is imperative that we, as a 
collective Indigenous nation, address the 'crisis of knowledge' that has resulted from 'not speaking' the tragic consequences of the past seven generations. Those unspoken narratives allowed inequities in caring, sharing and loving Creation's offerings for all our relations and all life on our Mother the planet Earth, whose diversity is self evident yet subject to disrespect and abuse, to be suffered. This tragic silence cannot continue because we have borne witness to the limits of survivability. It resonates loudly in the blood memory of all Indigenous people who continue to mourn those hurts. We know that one can be materially rich, but spiritually poor, and through experience we expect that future generations will question the reckless, destructive and selfish greed that now threatens mankind. And yet, as citizens of this earth too many continue to express little consideration for those from whom we borrow our lifetimes.

Canadian Indigenous scholar Neal McLeod credits Smith Atimoyoo, one of the founders of the Saskatchewan Indian Cultural College for teaching Indigenous people to use "new arrows" or "words that can be shot at the narratives of the colonial power” (McLeod, 2007). McLeod in his genre creating book Cree Narrative Memory: From Treaties to Contemporary Times, demonstrates the cultural revitalization of "coming home through stories" where past and present stories allow cultural transmission of the kind of struggles that help retain human dignity in the face of colonial dispossession, devastation and humiliation. He re-locates a story on "damn lazy Indians and the banishment to reserves":

\begin{abstract}
A long time ago, an old man and his grandson went to town. The boy was about fourteen. They had gone to town to buy groceries. They milled about the store and collected the items that they needed. After they filled their cart, there was a man by door. He said to his friend, "Damn lazy Indians." The man then went up to the old man and said, "You are god-damn lazy. Why can't you just stay on the reserve, where you belong?" The taunts continued, but the old man kept calm. After they gathered their groceries, they stood outside their vehicles. The grandson asked, "Nimosom, why didn't you say something to that man who was there, who was saying those things to us?" The grandfather answered his grandson with another question: "How long were we in the store?"“"Well, we were there for five minutes." "Yes, my grandson. We were in that store for five minutes. We had to deal with that man for five minutes. But he has to deal with himself for the rest of his life." (McLeod, 2007:68-69)
\end{abstract}

One of the most enriching experiences of graduate studies for this author was re-locating and reflecting on myths of who we are as people and what happened to our cultural pride. Seneca Indigenous scholar John Mohawk's (1994) Ph.D. thesis
"A View from Turtle Island: Chapters in Iroquois Mythology, History and Culture," gives long-overdue acknowledgement to the role of Indigenous women in fostering strong Indigenous communities. At the screening of a new documentary on the Six Nations land claim dispute at Caledonia titled "Six Miles Deep" I too was deeply impressed by the unrecognized magnitude of Indigenous women's work to bring a peaceful resolution to that 150 year-old struggle (Roque, 2009). The filmmaker stated she was using a new term making the rounds in Indian Country, "historicide" to denote the misrepresentations and misconceptions Canadians accept in their unawareness of the true history of colonial Canada. In a chapter entitled, "The Ancient Longhouse", Mohawk (1994) offers powerful endorsements to an enduring women-spirit and the extensive roles and responsibilities women have played to organize and orient Indigenous communities to communal harmony. Clan mothers and the older women of each longhouse prompted social efficacy and communal resilience, while effectively mediating sexual economy and respect through the negotiation of marriages. They knew the health of their men, their work habits, and who had desirable qualities for ensuring longhouse cohesion. Oversight of the development of their youth, including young men, gave clan mothers the authority to manage the formation of healthy relationships. Violence, especially sexual violence carried severe sanction, including possible death penalties, and therefore was rare. In addition, they held responsibility for preserving the land and maintaining agricultural fields for the benefit of the entire community. The coming of alcohol and the resultant cultural upheaval altered long held values and social order and created "mayhem and misery" in previously "gentle and loving communities" (Mohawk, 1994: 160). Blind adherence to prerogative power enabled the enslavement of those "vernacular cultures" who stood in the way of civilization and progress, and Mohawk states that, "Indigenous peoples are the ultimate vernacular cultures" (1994:20). They were societies based solely on reciprocity and interdependency on the lands they inhabit. Finally, Mohawk sees the inertia that followed the imposition of European colonial models of domestic enclosure of people for economic domination as something that led to reserves in the past, and, as leading to future ecological disaster for the future (Mohawk 1994:19-24).

The following extract from George J. Dei, Budd L. Hall, and Dorothy Goldin Rosenberg's (2002) book, Indigenous Knowledge in Global Contexts: Multiple Readings of Our World, summarizes what it can feel like to carry the responsibility to resist and rebel against ignorance, arrogance, and claims to innocence that transfer the obligation for transformative change to the victims of colonial excesses. Those excesses have permeated all human relations, infected the human condition with wanton disrespect, and ultimately challenge planetary 
survivability. Does the next human catastrophe beckon from unresolved historical lapses? Mohawk and others of his genre suggest that the restoration of good minds, good will, and good intentions are still possible through following ancient cultural imperatives.' He notes however that all humanity must re-locate good will across the artificial boundaries of superiority that have been created to privilege the few (Mohawk, 1994).

Should the world's Indigenous peoples fear Canada's suggested irresponsibly in oil sands exploitation, unfettered mining interests, or the depletion of sacred water resources? Perhaps globalization could best be regarded as modern colonization, which both endangers and disregards future generations. Through the following passage I wish to honor a powerful voice that comes very close to the oral traditions I have come to value within Indigenous cultures. The following treatise resonates with Indigenous expression on globalization and is presented mostly in its entirety:

Globalization has accelerated the flow of cultures across geographical, political, and cultural borders; it has also transformed knowledge into a commodity to which the most powerful in society usually lay unjustifiable claim. For indigenous peoples, the 'crisis of knowledge' can be seen in, or has resulted in, the following: fragmentation of traditional values and beliefs; erosion of spirituality; distortions in local, regional, and national ecosystems and economies; and tensions related to cultural revitalization and reclamation.

All knowledges exist in relation to specific times and places. Consequently, Indigenous knowledges speak to questions about location, politics, identity, and culture, and about the history of peoples and their lands. The process of teaching (and learning about) their histories and cultures is, for many Indigenous peoples, an act of political resistance to colonialized and imposed ways of knowing.

Indigenous knowledge's cannot be dismissed as mere localized phenomena. Such knowledges extend across cultures, histories, and geographical spaces, as well as across time. At different times many educators, community workers, and social activists have expressed theirfrustrations with the patriarchal colonizing practices of educational institutions... The negation, devaluation, and denial of Indigenous knowledges, particularly those of women, is the result of deliberate practices of establishing hierarchies of knowledge. This problem of knowledge hierarchies in homes, families, schools, and workplaces cannot be dismissed lightly; after all, such knowledge hierarchies have always shaped schools, communities, and political lives. Institutions are not unmarked spaces of thought and action. Knowledge forms are usually privileged to construct dominance, and can be 'fetishized' so as to produce and sustain power inequities. Fetishized knowledges are assigned or come to acquire an objectified, normal status, the status of truth. Thus they become embedded in social practices and identities, as well as in institutional structures, policies, and relationship... Indigenous knowledges, which have existed apart from colonial or imperial formations, are found at the very heart of the profound transformation of the world that is presently underway. (Dei, et al, 2000)

The above thoughts, while lengthy, capture the tenor of my thoughts as an Indigenous community worker and scholar after close to 30 years of First Nation community development work. I sought meta-narratives to explain how and why Indigenous peoples, the human beings that I identify with, continue to be mistreated, misunderstood, and even hated on their own lands. One of my heroes, Tekamthi (Tecumseh), declared that, "God gave us this country" (Gilbert, 1989), and I believe the land still resonates with that truth. The indifference to colonial injustice and the dismissive attitudes of far too many Canadian citizens for the human rights of Indigenous peoples is now an international stain wrought through political manipulation of the Declaration on Indigenous Rights. Early Canadian Treaty negotiations were also fraught with corruption, intimidation and predatory misrepresentations. The creating of suffering and 'poverty' to soften or weaken Indigenous peoples resolve has morphed into shameful mining practices by Canada in the north and around the world, but it hasn't ended there.

My understanding of the plight of Indigenous peoples in Canada is deeply informed by narratives gathered during a long community development and healing career in southern and northern Ontario. As a welfare worker during the 1980 recession, when the scandal of reckless investing led to the closure of the Massey-Ferguson combine factory in Brantford, I personally witnessed poverty intensely reflected in a sense of entitlement to privilege. This was an Ontario where my ancestral connection to the Six Nations of the Grand River First Nation was birthed; these actions forced my eyes open, but my powerlessness lay revealed, left impotent in a capitalistic wake.

In the 1980s and 1990s, I was a child welfare worker, suicide counselor and crisis worker, as well as a substance abuse treatment worker. My generation conceived and developed Toronto Aboriginal health and social services that were part of the recovery and renewal that has taken hold across Canada over the past twenty years. We were able to test models of hope and renewal that many other nations would ultimately emulate. Canadian Indigenous peoples are respected internationally for their work during the past 50 years, which reasserted a simple dignity and our human right to survival. We spoke the language of self-determination, railed against forced assimilation, and 
claimed lands which colonial states had stolen from Indigenous populations in their quest for domination, rampant greed, classism, and spiritual supremacy.

Most Canadians are not taught the significance of the Royal Proclamation of 1763 . This was the peace treaty that opened Canada for nationhood, through a mutual desire to protect the lands from gross exploitation. Canada’s citizens remain mostly uninformed about the very real resistance of Indigenous peoples to unlawful European expansion into Indigenous territories. European concepts of settlement and community formation in the 'New World' were amply endorsed by civil philosophers like Locke and Hobbes who promoted imperialistic selfinterest through the use of prerogative power (Arnold, 2007), and the concept of terra nullius or empty lands waiting for Christian settlement under the Christian Doctrine of Discovery (Mohawk, 2000). Indigenous world-views on place/territories of occupation opposed Eurocentric and massively destructive settlement patterns that were justified as taming wilderness and subduing primitives. As a continent, and as a society, we are now facing old/new cultural imperatives to actively consider sustainability for future generations. We are being forced to demystify the tragic consequences of those earlier ignorant and arrogant justifications for human misconduct. We are using words like cultural and environmental genocide, and warnings of tipping points generated by our use and abuse of natural resources to maintain our societal hunger for more, are no longer disregarded as hysterical. In this growing chaos, Aboriginal reserves, where poverty, poor water, poor education and poor health care are shameful realities, we can see a new normal developing. The Canadian government, with its inability to share resources, preserve commodities for future generations, or create healthy public trusts is eating itself from the inside out. We can all see the effects of deprivation, look to any Indian reserve in Canada that has been the recipient of Canada's inability to share its largesse with a singular and wanting population, masquerading in history as care and consideration. How can Canadian people trust that they will continue to benefit as recipients of these same lands when Canada has been so obviously duplicitous?

This paper ultimately became a reflective exercise of an Aboriginal man and scholar struggling to make sense of what the pathos/pathology of colonization on Canadian reserves represent in terms of our larger community. What I have seen is what community looks like when Canada fails to recognize the social, economic, political, spiritual upheavals colonization has embedded in its collective psyche. There can be no sense of wellbeing for Indigenous peoples enclosed on reserves governed by the colonial Canadian Indian Act of 1876 . We are the only people in this country governed by this antiquated legislation, with the door to change firmly shut in our faces. If community

(C) Steven W. Koptie development is a primary goal to help people improve their social and economic situation, and "to help people become subjects instead of objects, acting on their situation instead of simply reacting to it" (Chistenson et al., 1994:2), then the United Nations ratification of the Declaration of the Rights of Indigenous Peoples in 2007 must guide future Canadian social change agents onto the pathway of alleviating First Nations colonial poverty. Article 3 of the September 13, 2007 United Nations Declaration on the Rights of Indigenous Peoples which Canada failed to sign until 2010, and then only conditionally, relocates the path-way to recovery for First Nations communities:

Indigenous peoples have the rights to self-determination. By virtue of that right they freely determine their political status and freely pursue their economic, social and cultural development.

However, far too many Canadian minds are shielded from those truths' and they continue to endorse mythologies fomented during historical settlement in the past 150 years (Wesley-Esquimaux, CRE, 2009a). Chaotic dispossession of First Peoples lands and subsequent loss of their ability to be self-determining within their traditional Indigenous homeland, because they were under siege from disease and French and British settlers, is how the first seeds of dependency took root. Poverty has grown exponentially from those realities even though First Nation ancestors retained enough wisdom to fight for treaties and reserves until they could find ways to accommodated and adjust. Ratinyenkehaka (Mohawk) Elder Jan Longboat (2009) teaches that Indigenous natural sovereignty has never been surrendered. She calls for Indigenous people to strengthen spiritual ties to 'our place' and recover the 'richness' existing within traditional world-views and life-ways. Those are the ways that allowed us to feed ourselves, doctor ourselves, educate ourselves, and disciplined and maintained just societies for hundreds of generations before the experience of imposed dependency by settler states. Longboat (2009) claims we always had a richness that came from knowing how to plant gardens, hunt for sustenance, locate and extract the medicines we utilized for wellness, and to communicate in our beautiful languages. All of which made it possible to maintain good will and address Creation with gratitude. Our ancestors embedded through practice the worldviews and life-ways necessary for us to thrive in the places where we lived. Jan Longboat defined 'poorness' in terms of identifying suffering people who had lost the richness of collective reciprocity and interdependence, and who suffered cultural confusion. This can also be regarded as suffering from a 'poverty of spirit' in today's cultural vernacular. Hundreds of generations of self-determining peoples and the ancestral transfer of skills necessary to provide a good life for themselves and their families were undermined by contact. Thankfully, then 
and today, those that suffered extreme circumstances through poverty have been helped by other citizens equipped with exceptional abilities and a willingness to share beyond their own individual needs. Longboat (2009) suggests that there were also three orders of life giving instructions that survived, one for men, one for women, and one for both as parents and family members. External interference and the resulting pathology from adopting individualistic concepts of competitiveness and predatory interaction require more deliberation within our communities. Welfare dependency brought shame, distrust and a debilitating fear of starvation and loss. Reciprocity and interdependence were replaced by domination from Indian agents who could decide who received 'rations' and this became the first form of welfare. By examining the intentions of Canadian historical heroes and villains Indigenous scholars and writers can create new frameworks for re-telling remarkable resilience narratives to garner new insights, understandings, and interpretations of colonial experiences. These re-histories will become tools to reeducate dominant society on the intent of our ancestors when making Treaties and other accommodations for survival and their need to buy time to adapt to the colonial circus rapidly engulfing their traditional ways (Koptie, 2009a). They did what they had to do when relinquishing their natural sovereignty in times of destructive turmoil in their territories. If the alternative was total genocide then we must remember to honor their legacy to future generations (Tatz, 2003).

The coming struggle for sovereignty in Canada's Arctic region is another new frontier that will challenge the rights of all Canadians. Diplomacy at home is proving as difficult as good will abroad as Canada seeks truth and reconciliation of its historical colonial prerogative power abuses once used to confirm its claim to legitimate nationhood. The misrepresenting of an entire race of humanity allowed for immoral and illegal predatory settlement across Turtle Island, a process that continues to carry a level of great conflict, controversy and injustice with global implications for how nation states like Canada will be expected to conduct geographical and political relationships in the present and into the future. The need for alternative perspectives is great in this country, and Canada is fortunate to have a growing number of Indigenous scholars and writers to frame an identity beyond that of a colonial outpost. Aboriginal cultural, economic, political and spiritual contributions to Canadian identity are significant, albeit misunderstood, defining attributes for this country (Saul, 2008).

Five days in the Pikangikum First Nation "where the pavement ends" in northwestern Ontario can shake anyone's faith in Canada's identity as a modern state (Wadden, 2009). My entire world was shaken hard by two years of work with fly-in reserves where very little community development work has been done and the landscape is truly Third World or worse.
Here you find people who live within the boundaries of some of the richest gold mines in the world and yet continue to be amongst the world's poorest people. The pathos in communities like Pikangikum expresses everything about the truth of Canada's relationship to Indigenous people. This truth extends beyond Canadian borders where Canada's reprehensible mining practices are no longer a secret only First Nations endure. What I witnessed is beyond blaming the citizens of Pikangikum First Nation for not 'working in the mine.' This is a story about a people desperately clinging to their traditional homelands in the face of greed and an unrelenting quest for control of the natural resources that generate massive wealth used to sustain the population that lives south of the $60^{\text {th }}$ parallel. The successes of the $18^{\text {th }}, 19^{\text {th }}$ and $20^{\text {th }}$ centuries will haunt future generations of Canadian youth who will inherit our legacies of deceit and unresolved grievances. This author wishes to honour young Indigenous community activist Ben Powless from the Six Nations of the Grand River who is shining a light on Canada as a global colonial tyrant. Canada has foolishly transported its Aboriginal policies internationally hoping no one will notice just as no one notices what goes on in places like the Pikangikum First Nation and the ecological disaster of the Barrick gold minds in that region. Please Google Ben and follow his ecological struggles in protection of our Mother the Earth.

I researched one of Ontario's only resolved land claim and learned that when Canada negotiated Treaties it never expected reserves to last more than 100 years. The stark realities of Canadian justice were revealed while researching colonists such as Sir Francis Bond Head whose open contempt for the Red Man still reverberates through the annuls of settlement stalemates in southern Ontario and the rest of Canada. Sir Francis Bond Head stands as the great-great-grandfather of Canadian Indian Treaties and the creator of reserves. His tragic legacy would continue under the poet Duncan Campbell Scott, Sir John A. Macdonald's appointee to the Department of Indian Affairs in 1869 who set out to get rid of the Indian Problem by getting rid of the remaining Indians. The use of residential schools to deculture children and create poor living conditions on reserves were meant to force Indigenous peoples off their lands and into assimilation by the Canadian body politic. His response to a January 14, 1836 dispatch to imperial Britain's Lord Glenelg's inquiry on how to deal with Upper Canada's Indian question casts a sad shadow on Ontario's historical record. He observes:

"So long as we were obtaining Possession of their Country by open Violence, the fatal Result of the unequal Contest was but too easily understood; but now that we have succeeded in exterminating their Race from the vast Regions of Land, where nothing in the present Day remains of the poor Indian but the unnoticed Bones of his 
First Peoples Child \& Family Review, Volume 5, Number 2, 2010

\begin{abstract}
Ancestors, it seems inexplicable how it should happen, that even where the Race barely lingers in existence, it should still continue to wither, droop, and vanish before us like Grass in' the Progress of the Forest in Flames. 'The Red Men,' lately exclaimed a celebrated Miami Cacique, are melting like Snow before the Sun" (Shortt and Doughty 1914: pp. 331-362).
\end{abstract}

The words of Sir Francis Bond Head are emblematic of the rhetorical historic paradox and irony that promulgate the roots of myth regarding the settlement of Upper and Lower Canada. The final sentence of Bond-Head's writings, which all Indigenous scholars should study, clearly determines the trajectory to 'reservationization' in Canada. Agents like Sir Francis Bond Head legitimized the mythology of an inferior race in need of domination and state wardship until civilization took hold or they melted away before the sun like so much snow (Koptie, 2009c), but were those words really his own?

In 1811, Indigenous leader Miami Cacique, also known as Tecumseh, attempted to unite Indigenous peoples, which would lead to the War of 1812, in an effort to block conquest of the whole continent through American Manifest Destiny. Although, it is not my intention to unduly privilege the written word and reward the arrogance of Eurocentric translators, it is written that Tecumseh had the following to say in response to Bond Head's colonial hyperbole when he made a plea to the Choctaw and Chickasaw nations to assist in resisting genocide:

In view of questions of vast importance, have we met together in solemn council tonight... The whites are already nearly a match for us all united, and too strong for any one tribe alone to resist; so that unless every tribe unanimously combines to give check to the ambition and the avarice of the whites, they will soon conquer us apart and disunited, and we will be driven away from our native country and scattered as autumnal leaves before the wind. But have we not courage enough remaining to defend our country and maintain our ancient independence? Will we calmly suffer the white intruders and tyrants to enslave us? Shall it be said of our race that we knew not how to extricate ourselves from the three most dreadful calamities-folly, inactivity, and cowardice? But what need is there to speak of the past? It speaks for itself and asks, "Where today is the Pequod?" Where are the Mohawks, the Narragansetts, Pocanokets, and many other once powerful tribes of our race? They have vanished before the avarice and oppression of the white men as snow before the summer sun (DAH, 2003).

Out of respect for the oral traditions of the day, and recognizing that words were frequently and sometimes unfairly attributed to important leaders, I want to further acknowledge that Tecumseh was one of many Indigenous leaders who recognized the true intentions of settlement, 'reservationalization' and European prerogative power abuses sanctioned by the Doctrine of Discovery (Frishner, 2010). Those efforts still reside in global conflicts currently threatening mankind and the planet (Koptie, 2009c), and in the meditating of Indigenous success. Indigenous writers and scholars require culturally safe spaces to create descriptive pathways towards the correction and transformation of these outdated colonial mythologies. They need time and space to recover a multitude of ancestral world-views and long maintained life-ways that by most historical, Aboriginal, anthropological and spiritual accounts flourished successfully for thousands of years.

Renowned author, Farley Mowat re-tells a little known truth about Canadian colonization in his book Walking on the Land that the New York Times Book Review called "a provocative, alternative version of history, written by a master storyteller" (NYT, 2000). Farley Mowat (2000) recounts the use of stealth, starvation, removal and dispossession as mechanisms for destruction of the traditional ways of life of the Inuit in the interests of Canadian nation building. Farley Mowat (2000) pleads that his readers seek out narratives of Canadian historical injustices such as Tammarnit (Mistakes) by Tester and Kulchyski (1994), a scholarly review of Inuit relocations from 1939 to 1963 by the Canadian government:

The calamity in Keewatin that winter may have had something to do with Ottawa's subsequent decision to put the Ihalmiut under "the protection" of a pair of extrappers who were starting a commercial fishing business in northern Manitoba and who needed labour.

Early in April 1950, a policeman in a ski-equipped Otter flew to Ennadai and conducted what was, in effect, a forced deportation. Carrying little more than the clothing in which they stood, the Ihalmiut were flown in several relays to the south end of Nueltin Lake, well within forested country. Here they were left to become fisher folk. The fact that they had neither nets nor boats seems not to have troubled the authorities, who may have presumed the fish company entrepreneurs would provide the requisite equipment. This they never did. [Footnote by Mowat: Touted as a winter fishery that would deliver frozen fish by air to the railhead at Churchill, Manitoba two hundred miles away, the scheme had no prospects of success and was abandoned.]

Disoriented, fearful of the surrounding forests and of the Indians who inhabited them, and without any real means of making a living, the Ihalmuit sank into a kind of torpor [Encarta World English Dictionary definition: lack of mental or physical energy, numbness: absence of the ability to move or fell] from which they roused themselves 
only when one of their young women died in mysterious circumstances- possibly murdered.

The Ihalmuit fled. They walked home. It took five weeks for men, women, and children to traverse a distance of only about 150 air miles. Their journey entailed travelling more than twice that distance over some of the roughest country in Keewatin, around innumerable lakes, and across scores of rivers. The Israelites fleeing from Egypt had no greater difficulties to overcome. But in due course the Ihalmuit arrived back at the Little Lakes near Ennadai, where they began trying to reconstruct their lives.

Having lost much of their gear, they were unable to make adequate preparations for the coming winter. Indeed, all that saved them from famine was the presence of the weather station staff, from whom they received food enough to keep them alive until spring.

The events of that winter established a debilitating pattern. During succeeding years the Ihalmiut became increasingly reliant upon the weather station. From being a selfsustaining people they were insensibly transformed into a people of the dole. (Mowat, 2000:45-46)

Paul Watson addresses this atrocity in a recent Toronto Star article in which he reports from first hand survivors that, "the Inuit felt herded like animals" (November 29, 2009). "They were issued numbers stamped onto leather ID tags with the words "Eskimo Identification Canada" and the intent was to signal Canada's sovereignty of the north in the "Cold War' that followed the Great Wars of the $20^{\text {th }}$ century for European global supremacy. Indigenous warriors have fought in those conflicts, as Tecumseh fought before them, against tyranny and genocide only to return to the humiliations of Canadian Indian, Métis and Inuit social, economic, political and spiritual policies of dominance, degradation and 'dis-ease. Watson (2009) ponders the use of human subjects by Canada within the "Arctic lab," to assert sovereignty on the cheap. "It was an experiment for the government, to see if they could put people where there were no other people at all, and see if they could live completely on their own." This travesty continued the exiling of Indigenous peoples of North America to reserves, islands and locations far away from white people until as Sir Francis Bond Head proposed, "they could perish" or as Duncan Campbell Scott hoped, "they would be forced to assimilate and disappear into the Canadian body politic" (Crean, 2009: 62).

Indigenous writer, lawyer and businessman Calvin Helin in his controversial book Dances with Dependency: Indigenous Success through Self-Reliance, challenges the notions of "white solutions" for "Indian problems" as a never-ending stalemate between the quest for assimilation and the notion of economic integration, resource sharing and escape from the "poverty, dysfunction and nauseating dependency" existing within the "welfare trap" of most First Nations (Helin, 2006:100-103). Helin quotes from Harold Cardinal's 1999 book The Unjust Society;

Years ago our people were self-reliant... [from] trapping and ... whatever nature was able to provide us. Our life was hard... But we lived like men. Then the government came and offered welfare to our people... it was if they cut our throats. [Who] ... would go out to work or trap and face hardships of making a living when all he had to do was sit at home and receive the food, and all he needed to live? The government had laid a trap for us; for they knew once we accepted welfare they would have us where they wanted us. (Helin, 2006:103)

The controversy surrounding Calvin Helin's ideas is mostly political as he is an advisor to the Conservative Party of Canada. There is a great deal of distrust for policy that has evolved from Reform Party thinkers like Tom Flanagan from Calgary who believe that termination of all Indigenous rights will end the notion of "citizens plus" (Cairns, 2001), and special rights for First Nations in Canada. Flanagan (2000) warns in his book First Nations? Second Thoughts? that the current "aboriginal orthodoxy threads historical revisionism, critical legal studies and the aboriginal political activism of the last thirty years together and that,

...sooner or later Canada will be redefined as a multinational state embracing an archipelago of aboriginal nations that own a third of Canada's land mass, are immune from federal taxation, are supported by transfer payments from citizens who pay taxes, are able to opt out of federal and provincial legislation, and engage in 'nation to nation' diplomacy with whatever is left of Canada. Flanagan challenges all the key propositions of aboriginal orthodoxy including concepts like the inherent right to selfgovernment', 'sovereignty', and 'nationhood' as well as any recognition that aboriginal cultures were on the same level as those of European colonists. (Kopala, 2004)

History is repetitive and Tom Flanagan's thoughts reside in the same white supremacist mindset as Duncan Campbell Scott, Sir Francis Bond Head, and many other instigators of crimes against humanity. Tom Flanagan remains an outsider looking in and is not a member of those 'others' who are actively resisting the landscapes of dispossession, despair and pathology, which follow predatory colonization around the planet. Indigenous people look seven generations forward as well as backwards and not just at the past thirty years of conflict, where Tom Flanagan's fears of political, social and economic reconciliation are embedded. Perhaps he might benefit from reading Greg MacLeod's (2000) profound writings on sustainable 
community economic development, in MacLeod's great book, From Mondragon to America: Experiments in Community Economic Development. As an active participant in boards of directors, grant proposal writing and research that has lead to creating vital social services in child welfare, day care, health delivery, Fetal Alcohol Spectrum Disorder services as well as land claim negotiations, I have been able to directly experience much of the Aboriginal 'orthodoxy' to which Mr. Flanagan alludes.

My newest personal mantra comes from a February 2010 Canadian Roots Exchange youth program trip (www. canadianroots.ca) to the Mishkeegogamang (New Osnaburg House) Ojibway Nation in northern Ontario. This community is situated in the "Ring of Fire, a mineral deposit in northern Ontario that the Ontario government, in its 2010 Throne Speech, identified as the greatest mineral discovery in a century. I listened as their Chief, Connie Gray-McKay, mused, "we're tired of being the sandwich, we want to be the plate" expressing her frustration at watching wealth extracted from their traditional lands that does nothing to alleviate the heart wrenching poverty of her people.

Community recovery and reconciling injustices initiated by ignorance and insidious arrogance has been the service this author has participated in for close to thirty years. As a witness to the renaissance of Aboriginal struggles to reclaim resilience and recover dignity from the inhuman colonial inertia that allowed domination and degradation to define a whole race, I have no choice but to actively honour lessons learned from victims, survivors and victorizers in the Aboriginal community (WesleyEsquimaux, 2009b). Locating reflective topical biographic narratives from the courageous, persistent, and dedicated efforts of people like Don Jose Maria Arrrizmendiarrieta, who worked to restore dignity, pride and self-reliance to the small Basque community, Mondragon, has been glorious. People like Greg MacLeod (2000) provide First Nations with a profound escape route from dependency and a road map to self-determination, and social, economic, political and spiritual liberation from colonization. Canadian First Nations increasingly have access to the resources necessary to emulate Don Jose Maria's experiment in recovery and reclamation after a civil war defeat. The Basque Country Mondragon cooperative model holds valuable principles: Open Membership, Democratic Organization, Primacy of Work, Capital as a Means, Participation in Management, Wage Solidarity, Intercooperation, Social Transformation, Universal Mission and Education (MacLeod 2000:41). These ideals are also found in every Indigenous world-view in this country and stand as strong testimony to our future potential. The unique historical relationship the Basque have as interdependent, reciprocal people, parallels early connections of fisherman with North
American Indigenous people, neither of whom saw a need to conquer others. Here is an amazing post graduate research project just waiting for exploration and expression. Tom Flanagan can be left to debate free market, socialism and racial supremacy while Indigenous people re-assert the Primacy of Community and the Subordination of Capital (MacLeod 2000:91). Instead of maintaining "inferiorized" communities across Canada, the journey to collaboration, sustainability, selfdetermination and the making of a Canada that does with Indigenous peoples rather than for or to must be our first order of business as Indigenous scholars.

\section{References:}

Arnold, K. (2007). "Domestic War: Locke's Concept of Prerogative and Implications for U.S. "Wars" Today." Polity (39), 1-28. Available at www. palgrave-journals.com/polity.

Cairns, A. (2001). Citizens Plus: Aboriginal Peoples and the Canadian State, BC: University of British Columbia Press.

Cardinal, Harold (1999). The Unjust Society: With a New Introduction by the Author, Toronto: Douglas and McIntyre.

Christenson, J., K. Fendley and J. Robinson (eds.) (1994). Community Development in Community development in perspective. Christenson \& Robinson, Iowa: Iowa State University, 3-25.

Crean, S. (2009). Both Sides Now: Designing White Men and the Other Side of History. In Response, Responsibility, and Renewal: Canada's Truth and Reconciliation Journey, edited by Younging, G. J. Dewar, and M. Degagne. Ottawa: Dollco Printing.

Dei, George D. Sefa, Hall, B. and Goldin-Rosenberg, D. (Eds.). (2000). Indigenous knowledge in global contexts: Multiple readings of our world. Toronto, ON : University of Toronto Press.

Dictionary of American History (DAH). (2003). Sleep Not Longer, O Choctaws and Chickasaws (1811 by Tecumseh).

Dreier, P., Mollenkopf, J., and Swanstrom, T. (2001). Place Matters: Metropolitics For the twenty-first century. Lawrence, Kansas: University Press of Kansas1-27.

Ellison-Loschmann, L. (2003) Irihapeti Ramsden: Obituary, located at: http:// culturalsafety.massey.ac.nz/.

Erasmus, G. (2002). "The Lafontaine-Baldwin Lectures" Vancouver, BC: 2002, Online at: http:www.operationdialogue.com/lafontainebaldwin/e/2002_speech_4.html.

Flanagan, T. (2000). First Nations? Second Thoughts, McGill-Queen's University Press.

Frishner, T. (2010). Impact on Indigenous Peoples of the International Legal construct known as the Doctrine of Discovery. A Preliminary Study reported at the Ninth Permanent Forum on Indigenous Issues. New York, April 19-30, 2010.

Gilbert, B. (1989). God Gave Us This Country: Tekamthi and the First American Civil War, New York, NY: Anchor Books by Doubleday.

Harper, B. (2009). "Notes" from theG-20 Summit in Pittsburgh, United States of America, September 25, 2009.

Helin, C. (2006). Dances with Dependency: Indigenous Success through SelfReliance. Vancouver, BC: Orca Spirit Publishing. 


\section{Inferiorizing Indigenous Communities and Intentional Colonial Poverty}

Kopala, M. (2004). Daring to Challenge the Aboriginal Orthodoxy. Located at: http://www.margretkopala.com/news/mk26apr04.htm.

Koptie, S. (2009a). Metaphoric Reflections on the Colonial Circus of the Drunken Indian and the Kidney Machine. First Peoples Child and Family Review, Volume 4, Number 1, 2009, pp. 66-79.

Koptie, S. (2009b). Irihapeti Ramsden: The Public Narrative on Cultural Safety. First Peoples Child and Family Review, 4 (2), pp. 30-43.

Koptie, S. (2009c). After This Nothing Happened: Indigenous Academic Writing And Chickadee Peoples' Words. First Peoples Child and Family Review, 4(2),144-151.

Longboat, J. (2009). Traditional Teaching: "How to Create Healthy Dreams and Healthy Dreams", at Queen's University, $10^{\text {th }}$ Annual Aboriginal Symposium: "Spirituality", January 24, 2009.

Lyons, O. (2004). “The Ice is Melting”. The E. F. Schumacher Society: Online Source: https://www.smallisbeautiful.org/publications/lyons_04.html.

MacLeod, G. (2000). From Mondragon to America: Experiments in Community Economic Development. Sydney, NS: University of Cape Breton Press.

McLeod, N. (2007). Cree Narrative Memory: From Treaties to Contemporary Times. Saskatoon, SK: Purich Publishing.

Mohawk, J. (2000). Utopian Legacies: A History of the Conquest and Oppression in the Western World, New Mexico: Clear Light Publishers.

Mohawk, J. (1994). A View From Turtle Island: Chapters in Iroquois Mythology, History And Culture, Buffalo, NY: University of New York at Buffalo

Mowat, F. (2000). Walking on the Land, Toronto, ON: Key Porter Books Limited.

Rae, H. and Katz E. Trudel: The Movie. Boise, ID: Appaloosa Pictures and Balcony Releasing.

Ramsden, I. (2003). Cultural Safety and Nursing Education in Aotearoa and Te Waipounamu. Doctoral Thesis, located: http://www.culturalsafety. massey.ac.nz/.

Roque, Sara (director) (2009). Six Miles Deep. National Film Board of Canada. Produced by Lea Marin, Six Nations of the Grand River.

Saul, John Ralston (2008). A Fair Country: Telling Truths About Canada. Toronto : Penguin Goup, Canada.

Shortt, A, \& Doughty, A. (1914). Canada and Its Provinces, Volume V. Toronto, Glasgow : Brook and Company, pp. 331-362.

Soper, M.S. (2000) Being Human: the problem of agency. UK: Cambridge University Press.

Tatz, C. M. (2003). With intent to destroy: reflecting on genocide. Sydney, AUS: Verso Publishers.

Tester, J, \& Kulchyski, P. (1994). Tammarnit (Mistakes): Inuit relocation in the eastern Arctic 1939-1963. Vancouver, BC : UBC Press, p. 274-305.

Wadden, M. (2009). Where the Pavement Ends: Canada's Aboriginal Recovery Movement and the Urgent Need for Reconciliation. Vancouver, BC: Douglas \& McIntyre Publishers Inc.

Watson, Paul (2009). High Arctic Exiles, Video and Toronto Star Article, November 28-29, 2009.

Wesley-Esquimaux, C. (2009a). Shielded Minds, the video. Canadian Roots Exchange Youth Project, Centre for Aboriginal Initiatives, $\mathrm{U}$ of T.
Wesley-Esquimaux, C. (2009b). Trauma to Resilience: Notes on Decolonization, in Restoring the Balance: First Nations Women, Community, and Culture, Valaskakis, G., Madeline Dion-Stout, and Guimond (Eds.). Winnipeg, MB: University of Manitoba Press. 